\title{
The use of a multiscale approach in electrochemistry to study the corrosion behaviour of as-cast AZ91 magnesium alloy
}

\author{
Iwona $\operatorname{Kot}^{1} \cdot$ Halina Krawiec ${ }^{1}$
}

Received: 1 January 2015 /Revised: 2 May 2015 / Accepted: 6 May 2015 / Published online: 19 May 2015

(C) The Author(s) 2015. This article is published with open access at Springerlink.com

\begin{abstract}
The microstructure of as-cast AZ91 alloy is complex, with the presence of $\operatorname{Mg}_{17}(\mathrm{Al}, \mathrm{Zn})_{12}$ precipitates surrounded by an eutectic phase, AlMn intermetallic particles and an $\alpha-\mathrm{Mg}$ solid solution. In addition, the distribution of aluminium in the alloy was found to be heterogeneous. Under these conditions, a multiscale approach coupling global and local electrochemical measurements seems to be a promising method to study its corrosion behaviour. Results show that the multiscale approach can be used in $0.1 \mathrm{M} \mathrm{NaCl}$. In this case, AZ91 is susceptible to pitting corrosion. By contrast, the multiscale approach is not valid for AZ91 in $0.1 \mathrm{M} \mathrm{Na}_{2} \mathrm{SO}_{4}$. At the global scale, filiform corrosion and pitting corrosion are observed in the matrix, whereas only pits initiate when using the microcapillary techniques. The obtained results show that the local electrochemical techniques have to be used carefully in some environments.
\end{abstract}

Keywords Magnesium alloy $\cdot$ Polarisation $\cdot$ Pitting corrosion $\cdot$ Eutectic $\cdot$ Microcell technique

\section{Introduction}

Magnesium alloys are commonly used as structural materials in the automotive and aerospace sectors by virtue of their low densities and high strength-to-weight ratios. However, in spite of such attractive mechanical properties, their relatively low corrosion resistance is a serious obstacle to their widespread

Halina Krawiec

krawiec@agh.edu.pl

1 Faculty of Foundry Engineering, AGH-University of Science and Technology, Reymonta 23 Street, 30-059 Cracow, Poland application [1-4]. On account of its relatively low cost and excellent castability, AZ91 is one of the most widely used magnesium alloys [5]. It has been shown that its chemical composition has a fundamental influence on its corrosion behaviour and mechanical properties [5-9]. The addition of rare earth elements improves the mechanical properties of magnesium alloys, especially the ultimate tensile strength, but decreases their corrosion resistance [6,9]. Furthermore, the presence of a small amount of bismuth and antimony significantly increases the corrosion rate of magnesium alloys [10]. By contrast, some alloying elements such as silicon and calcium enhance the corrosion resistance of magnesium alloys [7, 9]: calcium improves the corrosion resistance through the formation of the reticular $\mathrm{Al}_{2} \mathrm{Ca}$ phase, which acts as an effective barrier against corrosion, while the combined addition of $\mathrm{Si}$ and $\mathrm{Sb}$ enhances the corrosion resistance of AZ91 alloy [7]. It has been shown that the addition of calcium oxide to AZ91 alloy improved its corrosion resistance due to higher pitting potential and the refinement of the precipitates [11]. A number of additions also ennobled the corrosion potential of AZ91. Addition of some elements, such as $\mathrm{Cr}$, Mo and $\mathrm{Y}$, leads to a shift of up to approximately 20 to $50 \mathrm{mV}$ towards more positive potential values. It was also noted [8] that the addition of $\mathrm{Y}(1$ or $2 \mathrm{wt} \%)$ induces a shift of the AZ91 corrosion potential to the anodic direction. By contrast, addition of a low content of Y $(0.1$ at. $\% \mathrm{Y})$ induces a significant decrease of the corrosion potential.

Many studies [12-32] have revealed that the corrosion behaviour of AZ91 alloy depends on the aluminium content and microstructure, particularly the amount and distribution of intermetallic phases and inclusions. The influence of intermetallic phases on the corrosion behaviour of magnesium alloys has been investigated in a number of papers $[4,13,14,16-21$, $23-30,32,33]$. It has been shown that an increase in Al content (8-9 wt\%) significantly improves the corrosion resistance 
of these alloys [23]. The AZ91 alloy consists of two intermetallic phases: $\beta-\mathrm{Mg}_{17} \mathrm{Al}_{12}$ and $\eta-\mathrm{Al}_{8} \mathrm{Mn}_{5}$. The presence of a eutectic structure has been observed around the $\beta$-phase. Song et al. $[26,29]$ showed that in sodium chloride solution, the free corrosion potential of the $\beta$-phase was $0.3 \mathrm{~V}$ more positive than that of the $\alpha$-phase, and this difference in free corrosion potential was observed to cause microgalvanic corrosion. According to results obtained through Scanning Kelvin Probe Force Microscopy, the $\beta-\mathrm{Mg}_{17} \mathrm{Al}_{12}$ and $\eta-\mathrm{Al}_{8} \mathrm{Mn}_{5}$ phases act as local cathodes when coupled to the $\alpha$-magnesium phase (matrix) under atmospheric conditions [17]. Moreover, strong dissolution of the matrix has also been detected around these particles $[19,20]$. Other studies $[34,35]$ have confirmed that the $\alpha$-phase is less noble than $\beta-\mathrm{Mg}_{17} \mathrm{Al}_{12}$. The higher corrosion resistance of the $\beta$-phase has been attributed to the formation of a passive film on its surface $[15,18]$. A similar occurrence was observed for $\eta-\mathrm{Al}_{8} \mathrm{Mn}_{5}$ particles in $1 \mathrm{M}$ $\mathrm{NaOH}$; this was followed by the formation of pits around these particles [36]. It has been shown that $\beta-\mathrm{Mg}_{17} \mathrm{Al}_{12}$ plays a dual role in the corrosion resistance of AZ91 alloy [24-26, 32]. Indeed, it can act as either a barrier or a galvanic cathode: as mentioned above, the corrosion potential of $\beta-\mathrm{Mg}_{17} \mathrm{Al}_{12}$ has been found to be more positive than that of the $\alpha$ magnesium phase (matrix), which may therefore accelerate the galvanic corrosion of $\alpha$-magnesium [21]. On the other hand, $\beta-\mathrm{Mg}_{17} \mathrm{Al}_{12}$ can, if present in the form of a continuous network, act as a corrosion barrier and hinder corrosion propagation in the matrix [24-26]. Lunder [19] showed that $\beta$ $\mathrm{Mg}_{17} \mathrm{Al}_{12}$ could reduce the corrosion rate of AZ91 by forming a corrosion-resistant barrier through the precipitation of an Alrich coring structure along grain boundaries.

It has been shown that the eutectic $(\alpha+\beta)$ and $\alpha-\mathrm{Mg}$ (matrix) phases have different aluminium contents [23, 26]. These dissimilar aluminium distributions give rise to different corrosion behaviours: areas with aluminium concentrations of less than approximately $8 \%$ have been found to be more prone to corrosion attack than areas with higher amounts of aluminium or areas containing the $\beta$-phase [13]. Both $\alpha$ magnesium and the eutectic phase can cause galvanic corrosion with the $\beta-\mathrm{Mg}_{17} \mathrm{Al}_{12}$ phase. According to microelectrochemical measurements performed in $0.1 \mathrm{M}$ $\mathrm{NaClO}_{4}$ solution, the eutectic phase is more susceptible to corrosion than $\alpha-\mathrm{Mg}$ (matrix) [37].

The casting method has a primary influence on the microstructure - and hence the corrosion resistance - of magnesium alloys. Die-cast material with smaller grain sizes and a fine $\beta$-phase has been found to exhibit marginally lower corrosion rates and better passivation compared with ingots [13]. Moreover, the heat treatment has influence on the microstructure of AZ91 alloy and its corrosion resistance. It has been shown [38] that the corrosion resistance of AZ91 decreases in $0.1 \mathrm{M} \mathrm{NaCl}$ solution as the $\mathrm{T} 6$ aging time increases (between 10 and $19 \mathrm{~h}$ ).
In the present, a multiscale approach coupling global and local electrochemical measurements is applied to AZ91 in $0.1 \mathrm{M} \mathrm{NaCl}$ and $0.1 \mathrm{M} \mathrm{Na}_{2} \mathrm{SO}_{4}$ solutions. Indeed, sulphate ions, like chloride ions, often tend to cause passivity breakdown and initiate pitting corrosion. In the literature, small attention has been paid to the behaviour of AZ91 in $\mathrm{Na}_{2} \mathrm{SO}_{4}$-based solutions. The domain of validity of the multiscale approach is first discussed. The electrochemical response of the system is then discussed taking into account the specimen microstructure and the approach considered (multiscale or global approaches).

\section{Experimental}

\section{Materials, specimens and surface preparation}

All experiments were performed on AZ91 magnesium alloy (chemical composition (wt\%): Zn 0.6, Al 9.03, Mn 0.2, Fe 0.003, Mg 90.2). This alloy was cast at $700{ }^{\circ} \mathrm{C}$ in a $\mathrm{SF}_{6} / \mathrm{CO}_{2}$ gas atmosphere to produce four $100 \times 100 \mathrm{~mm}^{2}$ plates of different thicknesses, namely 10,15, 20 and $30 \mathrm{~mm}$ for plates \#1, $\# 2$, \#3 and \#4, respectively. The mould used for the casting was made of a resin that was sand-hardened by $\mathrm{CO}_{2}$. No heat treatment or plastic deformation was carried out after casting. Microstructural and electrochemical investigations were performed on $2 \times 23 \times 27 \mathrm{~mm}^{3}$ (thickness $\times$ width $\times$ length) plate specimens, which were mechanically ground with silicon carbide ( $\mathrm{SiC}$ ) papers down to 4000 grit and polished using diamond pastes ( 3 and $1 \mu \mathrm{m}$ ). All specimens were ultrasonically cleaned in ethanol between each grinding/polishing operation.

\section{Electrochemical measurements and surface observations}

The electrochemical behaviour of specimens was studied in $0.1 \mathrm{M} \mathrm{NaCl}$ and $0.1 \mathrm{M} \mathrm{Na}_{2} \mathrm{SO}_{4}$ solutions at room temperature at both the global and local scales. All potentials were measured vs. $\mathrm{Ag} / \mathrm{AgCl}$ (3 M KCl solution). An AUTOLAB302N electrochemical interface with the Extreme Low Current Detection (ECD) module was used in order to achieve a current detection of approximately $1 \mathrm{fA}$. At both scales, potentiodynamic polarisation curves were plotted from $-2000 \mathrm{mV}$ vs. $\mathrm{Ag} / \mathrm{AgCl}$ in the anodic direction at a scan rate of $1 \mathrm{mV} \mathrm{s}^{-1}$.

Local measurements were performed using the electrochemical microcell technique [39-44]. The set-up for this technique consists of an electrolyte-filled glass capillary whose tip is adhered to the specimen surface with a layer of silicon rubber. The electrolyte used is aerated. This microcell is mounted onto a microscope to enable precise positioning of the capillary on the specimen surface. In our investigations, the capillary tip has a diameter ranging between 30 and $70 \mu \mathrm{m}$, depending on the microstructure that is studied. The counter electrode is a platinum wire. Each electrochemical 
measurement was repeated six times. As it will be discussed in the next sections, they were reproducible. By contrast, global measurements were carried out using a classical threeelectrode cell, whose counter electrode is a 2.5 -cm-diameter platinum disc. Global experiments were repeated twice. Results are found to be very reproducible.

A field-emission type scanning electron microscope (JEOL 6400F) with an integrated energy-dispersive spectrometer (FE-SEM/EDS) was used to determine the morphology and chemical composition of precipitates and metallic phases.

\section{Results and discussion}

The microstructure of AZ91 was already studied, and results are presented in [37]. In summary, AZ91 has a very complex microstructure composed of $\alpha-\mathrm{Mg}$ solid solution (dendrites), $\beta-\mathrm{Mg}_{17}(\mathrm{Al}, \mathrm{Zn})_{12}$ precipitates, AlMn intermetallic particles and a eutectic phase (Fig. 1). The chemical composition of these phases and particles is given in Table 1. Moreover, heterogenous distribution of aluminium is observed. Boundaries of $\alpha-\mathrm{Mg}$ dendrites are enriched in aluminium (Fig. 1 and Table 1). This necessarily implies highly heterogeneous electrochemical behaviour, which prompts us to study the corrosion behaviour of samples at the microscale using local electrochemical technique. However, it was already shown that under certain conditions, the microcell geometry may affect significantly local electrochemical measurements [42]. Therefore, both local and global (using a classical three-electrode cell) measurements have to be performed. Results obtained at both scales are systematically compared to each other. This is the multiscale approach. From this approach, it will be possible to study the relationships between the microstructure and the corrosion behaviour of AZ91 and to propose metallurgical

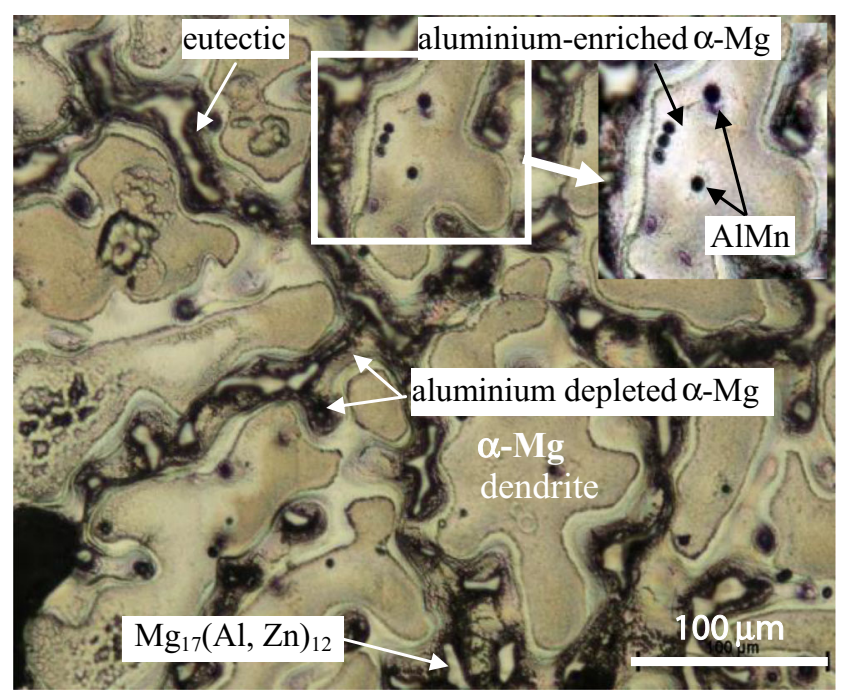

Fig. 1 Optical micrographs of the as-cast AZ91 alloy after etching in Nital solution for $10 \mathrm{~s}$ criteria leading to corrosion. Note that the double-channel microcapillary may be used to make a solution flow and to overcome certain limitations of the microcapillary cell [42, 44]. However, to obtain stable and reproducible results, the diameter of the double-channel capillary must be large (greater than $100 \mu \mathrm{m}$ ). This capillary size is not useful in the present study.

\section{Global and local electrochemical behaviour of AZ91 in $0.1 \mathrm{M} \mathrm{NaCl}$}

Figure 2a shows the open circuit potential (OCP) as a function of time for the AZ91 alloy in $0.1 \mathrm{M} \mathrm{NaCl}$ at both scales. Figure $2 b$ shows the types of sites that were investigated at the microscale, namely the $\alpha-\mathrm{Mg}$ matrix (centre of dendrites), the matrix containing the $\beta$-phase, the matrix containing AlMn precipitates and the matrix containing both the $\beta$ phase and AlMn precipitates. In this figure, the diameter of the circles corresponds to that of the capillary.

At the global scale (grey curve in Fig. 2a), a steady state is reached after roughly $700 \mathrm{~s}$ of immersion. At the local scale, the time necessary to reach a steady state was found to depend on the investigated site. A steady state is also quickly reached in the presence of the matrix with $\beta$-phase (red curve in Fig. 2a) or with AlMn particles (blue curve in Fig. 2a). In sites containing $\beta$-phase $+\mathrm{AlMn}+\alpha-\mathrm{Mg}$ matrix (green curve in Fig. 2a), the steady state is only reached after $6000 \mathrm{~s}$ of immersion. The OCP values measured at the local scale are between $-1345 \mathrm{mV}$ vs. $\mathrm{Ag} / \mathrm{AgCl}$ (sites with the matrix $+\beta$ phase $+\mathrm{AlMn}$ particles) and $-1640 \mathrm{mV}$ vs. $\mathrm{Ag} / \mathrm{AgCl}$ (matrix). This confirms that the sample has a heterogeneous electrochemical behaviour. The lowest OCP is recorded for the $\alpha$ Mg matrix (black curve in Fig. 2a), suggesting that the primary $\alpha-\mathrm{Mg}$ phase is the most prone to corrosion. In addition, the OCP measured at the global scale follows the same evolution as that of sites containing the matrix with AlMn (OCP around $-1510 \mathrm{mV}$ vs. $\mathrm{Ag} / \mathrm{AgCl})$.

Figure 3 shows the polarisation curves of AZ91 in $0.1 \mathrm{M}$ $\mathrm{NaCl}$ at both scales. First, it can be observed that in the cathodic domain, the global polarisation curve follows the same evolution as those of sites containing the matrix with AlMn (as it was found for the OCP). Therefore, cathodic reactions occur preferentially in those sites. The anodic branch of the global polarisation curve indicates active behaviour, with a sharp increase in current density as soon as the corrosion potential is reached (of about $-1380 \mathrm{mV}$ vs. $\mathrm{Ag} / \mathrm{AgCl}$ ). At these applied potentials, the $\alpha-\mathrm{Mg}$ matrix located in the centre of dendrites becomes active (black curves in Fig. 3a). Pitting potentials are between -1350 and $-1250 \mathrm{mV}$ vs. $\mathrm{Ag} / \mathrm{AgCl}$. The local curves obtained in these sites are very reproducible. Figure 4(a1) and (b1) shows a pit that initiated in one of these types of sites during local potentiodynamic measurements. 
Table 1 Chemical composition (in at.\%) of phases and particles in the AZ91 alloy determined by means of FE-SEM/EDS. Each value is an average of 10 measurements. The error is the standard deviation

\begin{tabular}{|c|c|c|c|c|c|c|c|}
\hline & $\mathrm{Al}$ & $\mathrm{Mn}$ & $\mathrm{Mg}$ & $\mathrm{Zn}$ & $\mathrm{O}$ & $\mathrm{Ni}$ & $\mathrm{Cu}$ \\
\hline AlMn & $38.1 \pm 2.0$ & $44 \pm 5.0$ & & & & & \\
\hline$\beta-\mathrm{Mg}_{17}(\mathrm{Al}, \mathrm{Zn})_{12}$ & $33.3 \pm 3.0$ & $0.3 \pm 0.05$ & $61.3 \pm 4.0$ & $3.4 \pm 0.8$ & $1 \pm 0.06$ & $0.37 \pm 0.02$ & $0.2 \pm 0.05$ \\
\hline Centre of dendrites & $2.9 \pm 0.7$ & & $96.9 \pm 3.0$ & & & & \\
\hline Boundaries of dendrites & $7.1 \pm 1.0$ & & $90.6 \pm 2.0$ & $0.5 \pm 0.03$ & & & \\
\hline
\end{tabular}

The polarisation curves of sites containing both the matrix and the $\beta$-phase are also reproducible (red curves in Fig. 3b). The values of the pitting potential measured at these sites are similar to those for the matrix in the centre of dendrites, ranging between -1350 and $-1250 \mathrm{mV}$ vs. $\mathrm{Ag} / \mathrm{AgCl}$. Thus, it appears that pits initiate in the matrix, and the presence of the $\beta$-phase at these sites has virtually no influence on the
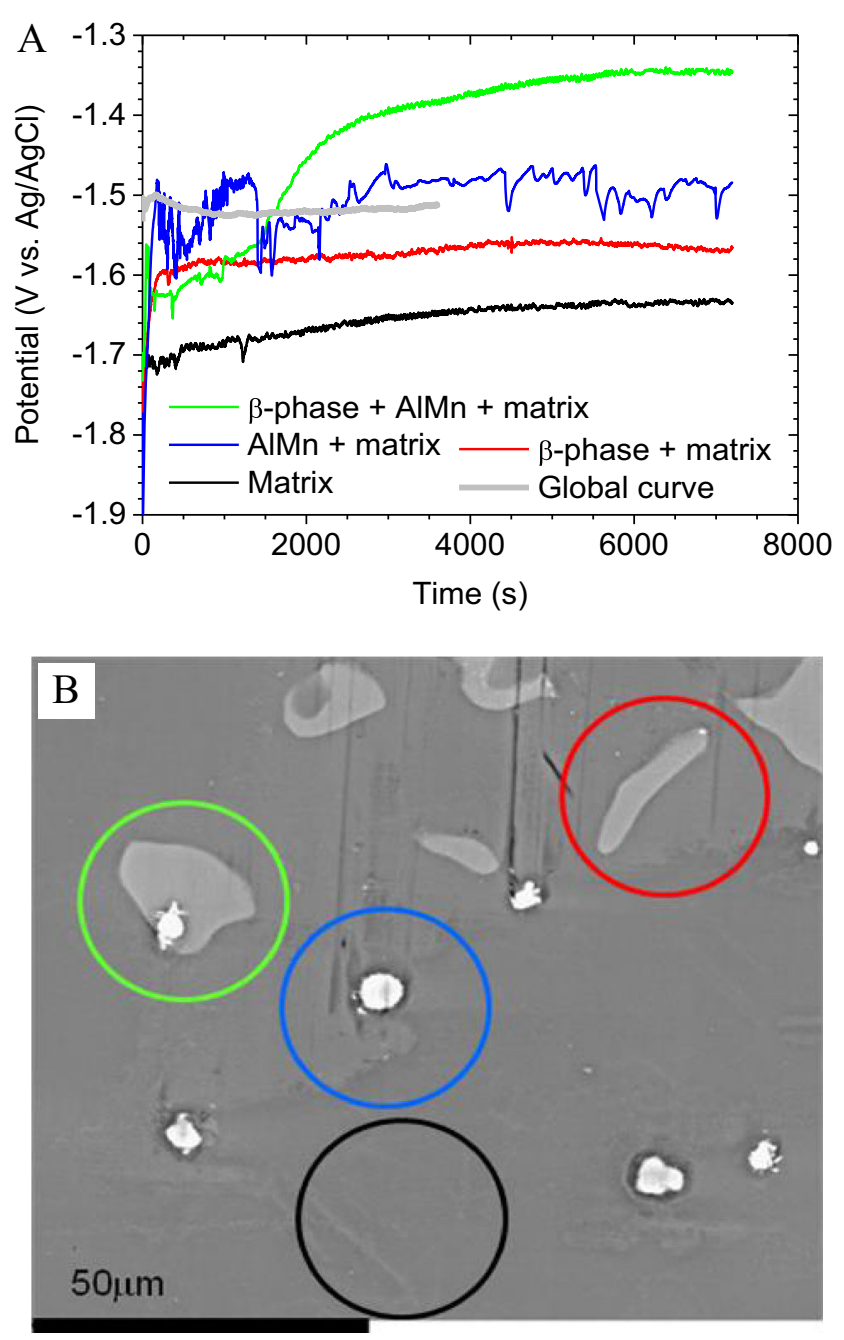

Fig. 2 a Evolution of the OCP of AZ91 in $0.1 \mathrm{M} \mathrm{NaCl}$ at the local (capillary diameter of $35 \mu \mathrm{m}$ ) and global scales. Experiments were performed after mechanical polishing. b Optical micrograph showing the different sites where local measurements were carried out (capillary positions indicated by circles) value of the pitting potential. No significant differences are also observed in the current density in the cathodic domain and in the corrosion potentials between black (matrix) and red ( $\beta$-phase + matrix) curves in Fig. 3a, b. Subsequent surface observations confirm this hypothesis. We observe that many pits initiate at regions in the matrix far from the $\beta$-phase (cf. Fig. 4(a2) and (b2) and site 1 in Fig. 4(b3)). Nonetheless, there are some other pits that initiate at the interface between the matrix and the $\beta$-phase (sites 2 and 3 in Fig. 4(b3)). It is interesting to note that the role of $\beta$-phase may be affected
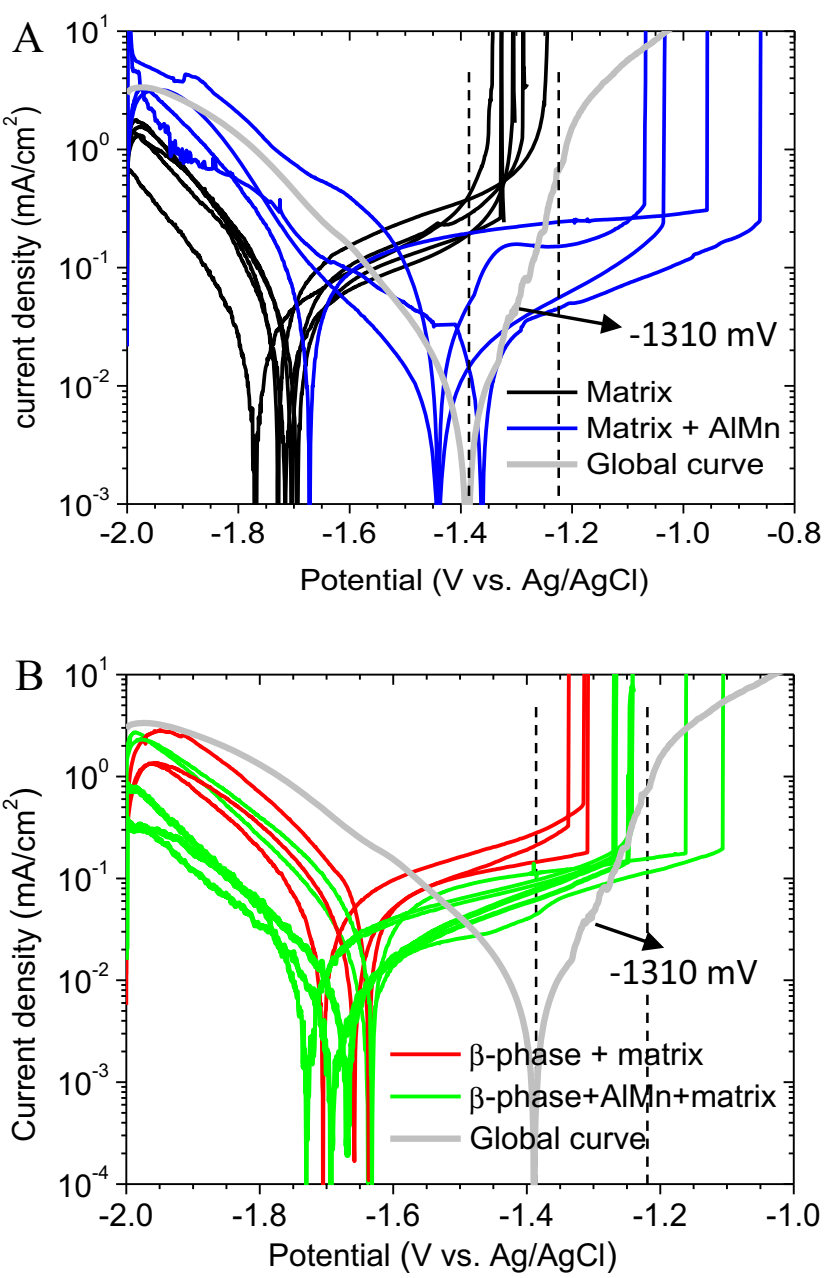

Fig. 3 a-b Polarisation curves $\left(1 \mathrm{mV} \mathrm{s}^{-1}\right)$ in $0.1 \mathrm{M} \mathrm{NaCl}$ at the local (35 $\mu \mathrm{m}$ diameter capillaries) and global scales. Experiments were performed after mechanical polishing 

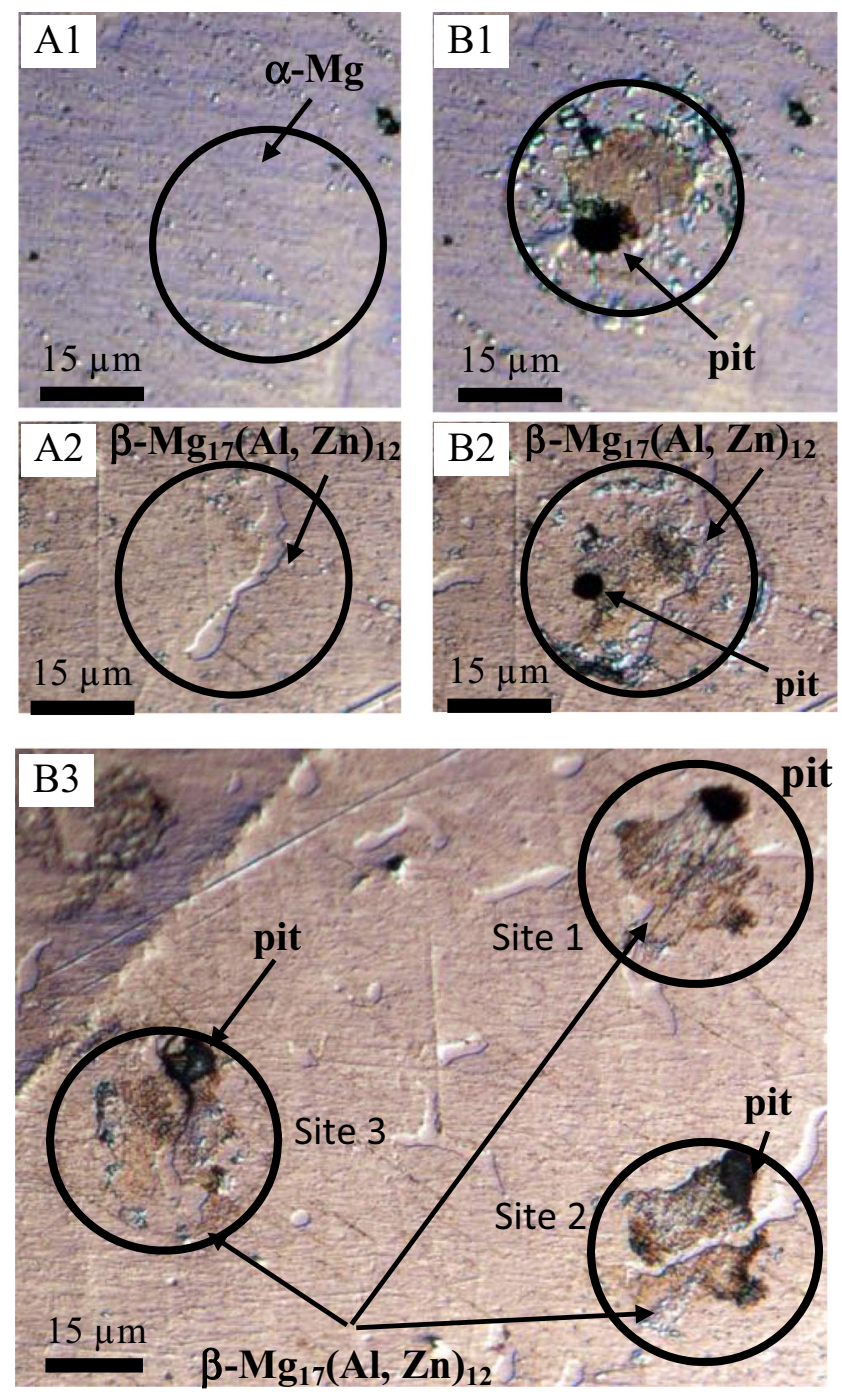

Fig. 4 Optical micrographs of the AZ91 surface after: (a1-a2) mechanical polishing and (b1-b3) local electrochemical measurements (polarisation curves) in $0.1 \mathrm{M} \mathrm{NaCl}$. The diameter of the capillary (black circles) was $35 \mu \mathrm{m}$

by the presence of AlMn. Indeed, when comparing polarisation curves measured in the matrix with AlMn (blue curves in Fig. 3a) and the matrix with both $\beta$-phase and AlMn (green curves in Fig. $3 b$ ), the presence of $\beta$-phase clearly affects the current density in the cathodic branch and open circuit potential.

Other sites remain passive up to greater applied potentials. A large dispersion in pitting potentials is observed in the presence of AlMn precipitates (blue curves in Fig. 3a). Indeed, they range between -1300 and $-850 \mathrm{mV}$ vs. $\mathrm{Ag} / \mathrm{AgCl}$, indicating that these sites were generally more resistant to pitting corrosion than the matrix. This behaviour can be linked to the enrichment in $\mathrm{Al}$ observed in the matrix surrounding AlMn. These particles are mainly located at the $\alpha-\mathrm{Mg}$ dendrites boundaries (region enriched in Al), Fig. 1. Moreover, recent work has confirmed the beneficial effect of Mn on corrosion resistance of AZ91 alloy [45].
To confirm previous results, a global chronoamperometry test was performed at $-1310 \mathrm{mV}$ vs. $\mathrm{Ag} / \mathrm{AgCl}$ for $60 \mathrm{~s}$. Figure 5a shows an optical micrograph of the specimen surface after this test. The metallic matrix underwent strong dissolution. Numerous pits are observed in the matrix, most of which are located in the centre of $\alpha-\mathrm{Mg}$ dendrites where the aluminium content is low (less than 3 at.\%, Table 1 and reference [37]). The average pit diameter is $20 \mu \mathrm{m}$, although a few of the pits are larger than this. By contrast, the $\beta-\mathrm{Mg}_{17}(\mathrm{Al}, \mathrm{Zn})_{12}$ and AlMn phases did not undergo dissolution. Therefore, previous assumptions are confirmed. Figure $5 \mathrm{~b}$ shows the specimen surface after global chronoamperometry test at $-1310 \mathrm{mV}$ vs. $\mathrm{Ag} /$ $\mathrm{agCl}$ for $60 \mathrm{~s}$. FE-SEM/EDS analysis was performed in different sites visible in Fig. $5 \mathrm{~b}$ containing $\beta-\mathrm{Mg}_{17}(\mathrm{Al}, \mathrm{Zn})_{12}$ (site 1 in Fig. 5b), the matrix (sites 2 and 3 in Fig. 5b) and AlMn intermetallic particles (site 4 in Fig. 5b). Data are reported in Table 2. It can be seen that the surface is generally slightly oxidised (oxygen content around 2-3 at.\%). Sites containing AlMn intermetallic particles are the most oxidised sites (oxygen content around 25 at.\% in Table 2). No highly resistant oxide film covers the specimen surface. This explains why only pitting corrosion is observed (and not filiform corrosion).

Under these conditions, corrosion of magnesium and its alloys - which involves substrate dissolution, Mg-hydroxide formation and hydrogen evolution - proceeds according to Reactions (1-7). The overall reaction is given by Reaction (8).

$\mathrm{Mg} \rightarrow \mathrm{Mg}^{2+}+2 \mathrm{e}$

(anodic reaction, standard potential : $-2.375 \mathrm{~V}$ vs. NHE)

$2 \mathrm{H}_{2} \mathrm{O}+2 \mathrm{e} \rightarrow \mathrm{H}_{2}+2 \mathrm{OH}^{-}$

(cathodic reaction, standard potential : $-0.827 \mathrm{Vvs}$. NHE)

$\mathrm{Mg}+2 \mathrm{H}^{+}+2 \mathrm{e} \rightarrow \mathrm{MgH}_{2}$

(standard potential : $-1.085 \mathrm{Vvs.} \mathrm{NHE)}$

$\mathrm{Mg}^{2+}+2 \mathrm{H}^{+}+4 \mathrm{e} \rightarrow \mathrm{MgH}_{2}$

(standard potential : $-1.114 \mathrm{~V}$ vs. NHE)

$\mathrm{Mg}^{2+}+2 \mathrm{OH}^{-} \rightarrow \mathrm{Mg}(\mathrm{OH})_{2}$

$\mathrm{MgH}_{2} \rightarrow \mathrm{Mg}^{2+}+\mathrm{H}_{2}+2 \mathrm{e}$

(standard potential : $-2.170 \mathrm{~V} v$ s. NHE)

$\mathrm{MgH}_{2}+2 \mathrm{OH}^{-} \leftrightarrows \mathrm{Mg}(\mathrm{OH})_{2}+\mathrm{H}_{2}+2 \mathrm{e}$

(standard potential : $-1.67 \mathrm{Vvs}$. NHE)

$\mathrm{Mg}+\mathrm{H}_{2} \mathrm{O} \rightarrow \mathrm{Mg}(\mathrm{OH})_{2}+\mathrm{H}_{2}$ 

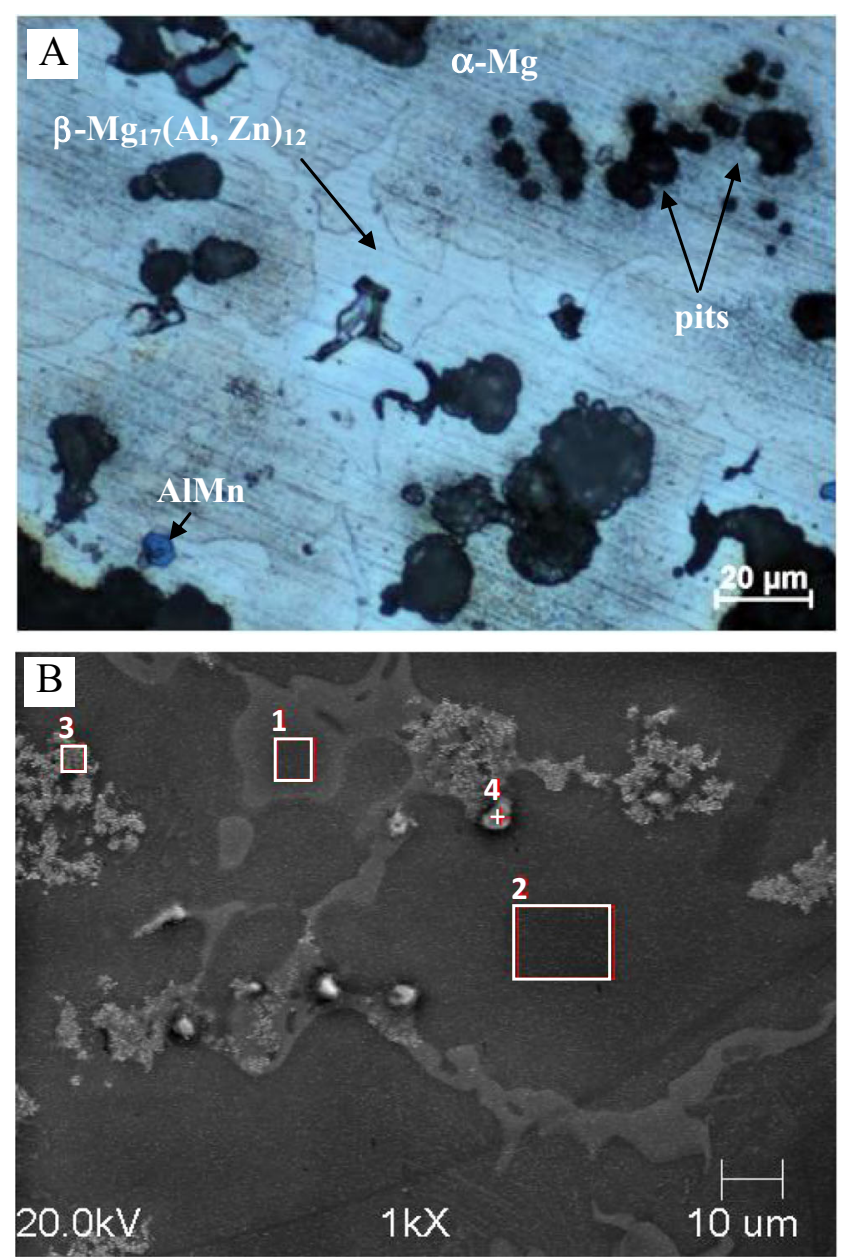

Fig. 5 a Optical and b SEM-FE micrographs of the AZ91 alloy surface after global chronoamperometry test in $0.1 \mathrm{M} \mathrm{NaCl}$ at $-1310 \mathrm{mV}$ vs. $\mathrm{Ag} /$ $\mathrm{AgCl}$ for $60 \mathrm{~s}$

The aluminium content in the matrix with corrosion products (Site 3, Table 2) is higher than that in the matrix (site 2, Table 2), indicating that the corrosion products may also contain Al-Mg-O compounds (maybe $\left.\mathrm{MgAl}_{2}(\mathrm{OH})_{8} * \mathrm{H}_{2} \mathrm{O}\right)$. The presence of $\mathrm{MgAl}_{2}(\mathrm{OH})_{8} * \mathrm{H}_{2} \mathrm{O}$ was already proposed in $[46,47]$. Therefore, the main corrosion products should be $\mathrm{Mg}(\mathrm{OH})_{2}$ and $\mathrm{MgAl}_{2}(\mathrm{OH})_{8} * \mathrm{H}_{2} \mathrm{O}$. In addition, Baril and Pebere [48] found that the presence of oxygen did not influence the cathodic reaction during the corrosion of $\mathrm{Mg}$.

In the case of $\mathrm{AZ91}$ in $0.1 \mathrm{M} \mathrm{NaCl}$, the cell geometry does not affect the electrochemical response of the system. The multiscale approach can then be used to investigate corrosion mechanisms. It was shown that (i) the matrix is prone to pitting corrosion, (ii) the $\beta$-phase has virtually no influence on the value of the pitting potential, and (iii) sites containing AlMn precipitates are more resistant to pitting corrosion, (iv) cathodic reactions preferentially occur at sites containing the matrix with AlMn. In addition, local measurements can be helpful to build a model with physical meaning (using relationships between electrochemical measurements and the microstructure described above) and to provide quantitative data (pitting potentials, cathodic current densities...) which can be used as boundary conditions in predictive numerical simulation. These quantitative data have never been quantified for AZ91 in the literature.

\section{Global and local electrochemical behaviour of AZ91 in $0.1 \mathrm{M} \mathrm{Na}_{2} \mathrm{SO}_{4}$}

The multiscale approach was also applied to AZ91 in $0.1 \mathrm{M}$ $\mathrm{Na}_{2} \mathrm{SO}_{4}$. By contrast to $0.1 \mathrm{M} \mathrm{NaCl}$, there is no good agreement between local and global measurements in $0.1 \mathrm{M}$ $\mathrm{Na}_{2} \mathrm{SO}_{4}$. The OCP measured at the global scale increases continuously (to reach a value of about $-1450 \mathrm{mV}$ vs. $\mathrm{Ag} / \mathrm{AgCl}$ after $7000 \mathrm{~s}$ of immersion), and no steady state is attained (grey curve in Fig. 6). This is attributed to the formation of a corrosion product film at the sample surface. As already discussed, the main corrosion products are $\operatorname{Mg}(\mathrm{OH})_{2}$ and

Table 2 Chemical composition (in at.\%) of various sites at the specimen surface (AZ91 alloy) determined by means of FE-SEM/EDS after different corrosion tests

\begin{tabular}{|c|c|c|c|c|c|c|c|}
\hline & $\mathrm{Al}$ & $\mathrm{Mg}$ & $\mathrm{Zn}$ & $\mathrm{O}$ & $\mathrm{S}$ & $\mathrm{Cl}$ & $\mathrm{Mn}$ \\
\hline Site 1 in Fig. $5 b, \beta-\mathrm{Mg}_{17}(\mathrm{Al}, \mathrm{Zn})_{12}$ & 30.8 & 65.4 & 0.95 & 2.6 & - & 0.2 & 0 \\
\hline Site 2 in Fig. 5b, matrix & 3.24 & 93 & 0 & 3.4 & - & 0.24 & 0 \\
\hline Site 3 in Fig. 5b, matrix with corrosion products & 21.2 & 65.3 & 0.6 & 12.7 & - & 0.17 & 0 \\
\hline Site 4 in Fig. 5b, AlMn & 36.8 & 12.4 & 0 & 25.3 & - & 0.1 & 23.7 \\
\hline Site 1 in Fig. $8 \mathrm{a}, \beta-\mathrm{Mg}_{17}(\mathrm{Al}, \mathrm{Zn})_{12}$ & 32.1 & 60.2 & 1.9 & 5.5 & 0.28 & - & 0 \\
\hline Site 2 in Fig. 8 a, matrix & 5.7 & 64.7 & 0.5 & 28.5 & 0.6 & - & 0 \\
\hline Site 1 , in Fig. 8 b, matrix & 7.7 & 23.8 & & 64.6 & 4 & - & 0 \\
\hline Site 2 in Fig. $8 b, \beta-\mathrm{Mg}_{17}(\mathrm{Al}, \mathrm{Zn})_{12}$ & 32.1 & 59.9 & 2 & 5.9 & & - & 0 \\
\hline Site 1 in Fig. $9 \mathrm{c}, \beta-\mathrm{Mg}_{17}(\mathrm{Al}, \mathrm{Zn})_{12}$ & 28.3 & 64.9 & 1.8 & 4.8 & 0.4 & - & 0 \\
\hline Site 2 in Fig. 9c, matrix & 4.4 & 63 & 0.2 & 30.9 & 1.6 & - & 0 \\
\hline Site 3 in Fig. 9c, eutectic & 7.3 & 84.8 & 0.8 & 7 & 0.2 & - & 0 \\
\hline
\end{tabular}




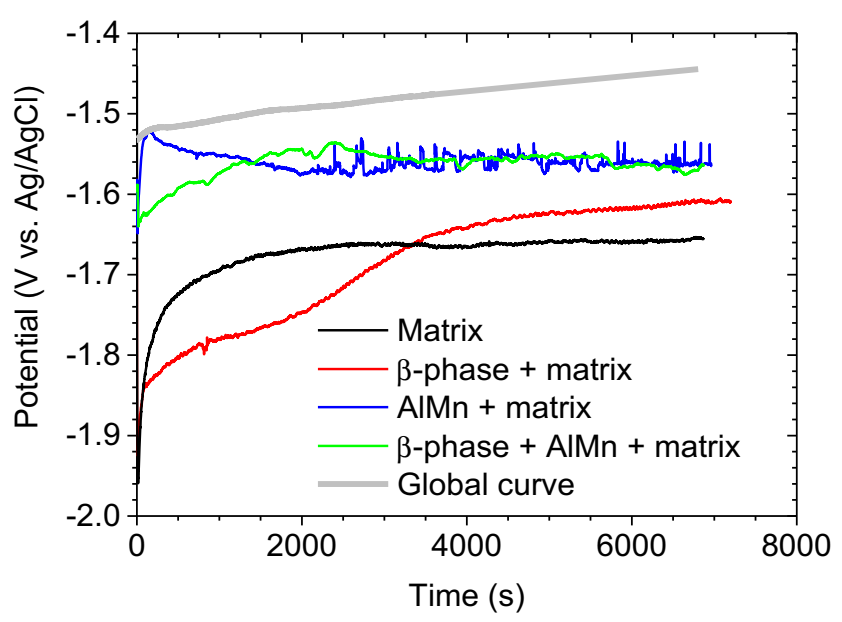

Fig. 6 Evolution of the OCP of AZ91 in $0.1 \mathrm{M} \mathrm{Na}_{2} \mathrm{SO}_{4}$ at the local (capillary diameter of $35 \mu \mathrm{m}$ ) and global scales. Experiments were performed after mechanical polishing

$\mathrm{MgAl}_{2}(\mathrm{OH})_{8} * \mathrm{H}_{2} \mathrm{O}$. In aqueous solutions containing $\mathrm{SO}_{4}{ }^{2-}$ ions [47], corrosion of AZ91 alloy proceeds at OCP according
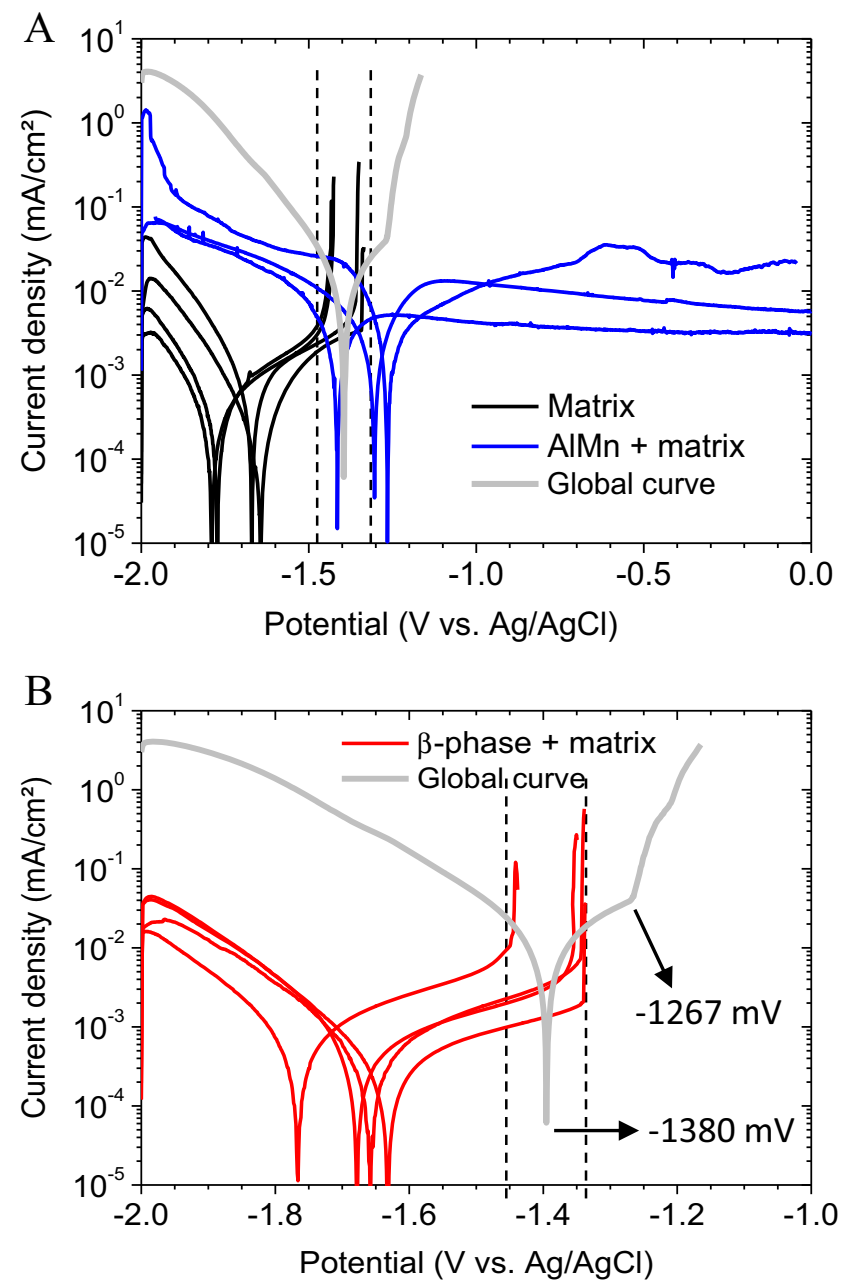

Fig. 7 a-b Local polarisation curves $(35 \mu \mathrm{m}$ diameter capillaries, $1 \mathrm{mV} \mathrm{s}^{-1}$ ) for different sites in $0.1 \mathrm{M} \mathrm{Na}_{2} \mathrm{SO}_{4}$, after mechanical polishing. Global curves are also reported (grey curves) to reactions (1) and (9-10). Moreover, $\mathrm{SO}_{4}{ }^{2-}$ ions can be reduced, and reactions (11-12) can also proceed.

$\mathrm{Mg}^{2+}+2 \mathrm{Al}^{3+}+4 \mathrm{SO}_{4}^{2-}+22 \mathrm{H}_{2} \mathrm{O} \rightarrow \mathrm{MgAl}_{2}(\mathrm{SO})_{4} * 22 \mathrm{H}_{2} \mathrm{O}$
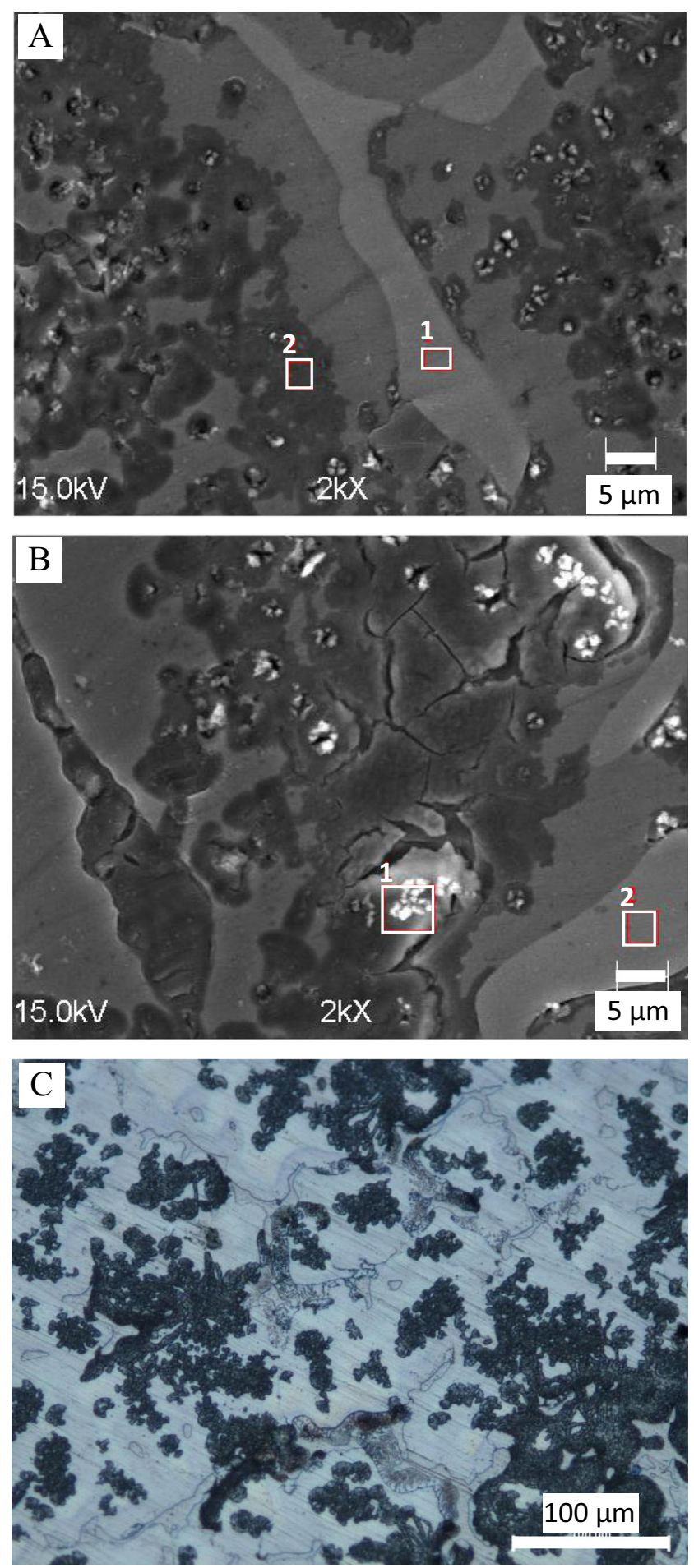

Fig. 8 a-b FE-SEM and c optical micrographs of the AZ91 surface after global chronoamperometry test in $0.1 \mathrm{M} \mathrm{Na}_{2} \mathrm{SO}_{4}$ at $-1320 \mathrm{mV}$ vs. $\mathrm{Ag} /$ $\mathrm{AgCl}$ for $60 \mathrm{~s}$ 


$$
\begin{aligned}
& \mathrm{Mg}^{2+}+\mathrm{SO}_{4}^{2-} \rightarrow \mathrm{MgSO}_{4} \\
& \mathrm{SO}_{4}^{2-}+\mathrm{H}_{2} \mathrm{O}+2 \mathrm{e} \rightarrow \mathrm{SO}_{3}^{2-}+2 \mathrm{OH}^{-} \\
& \text {(standard potential : }-0.93 \mathrm{~V} \text { vs. NHE) } \\
& 2 \mathrm{SO}_{3}^{2-}+3 \mathrm{H}_{2} \mathrm{O}+4 \mathrm{e} \rightarrow \mathrm{S}_{2} \mathrm{O}_{3}^{2-}+6 \mathrm{OH}^{-} \\
& \text {(standard potential : }-0.571 \mathrm{Vvs} \text {. NHE) }
\end{aligned}
$$

Alkalization of the solution and formation of $\mathrm{Mg}(\mathrm{OH})_{2}$ at the specimen surface are expected (reactions (2), (11) and (12)). This may hinder the formation of $\mathrm{MgH}_{2}$ in $0.1 \mathrm{M}$ $\mathrm{Na}_{2} \mathrm{SO}_{4}$ solution.

By contrast, a steady state is attained at the local scale for all investigated sites after approximately $4000 \mathrm{~s}$ of immersion (Fig. 6). The OCP values determined at the local scale (between -1660 and $-1560 \mathrm{mV}$ vs. $\mathrm{Ag} / \mathrm{AgCl}$ ) are shifted to the cathodic direction compared to that measured at the global scale $(-1450 \mathrm{mV}$ vs. $\mathrm{Ag} / \mathrm{AgCl})$. This suggests that no film was formed during the local tests. Therefore, one may assume that dissolved oxygen may be quickly consumed in the capillary near the specimen surface preventing both strong oxidation of the matrix and the formation of the corrosion products film. By contrast, dissolved oxygen is not quickly consumed in the classical three-electrode cell near the specimen surface, and strong oxidation is observed. In the case of AZ91 in $0.1 \mathrm{M}$ $\mathrm{Na}_{2} \mathrm{SO}_{4}$, the cell geometry seems to affect the corrosion mechanisms, and the electrochemical microcell technique has to be used carefully. The current density measured in the cathodic domain of local polarisation curves is significantly lower than that measured at the global scale (Fig. 7). Cathodic reactions correspond to dissolved oxygen and water reduction. Therefore, this confirms that dissolved oxygen may be quickly consumed in the capillary near the specimen surface and that under these conditions, the electrochemical microcell technique has to be used carefully. Additionally, the strong alkalization of the environment (reduction reactions: (2), (11) and (12)) has significant influence on the corrosion behaviour at the local scale.

The global polarisation curve of AZ91 obtained with the $\mathrm{Na}_{2} \mathrm{SO}_{4}$-based solution reveals the presence of a two-stage breakdown mechanism (grey curve in Fig. 7). The first stage occurs for applied potentials greater than $E_{\mathrm{b} 1}=-1380 \mathrm{mV}$ vs. $\mathrm{Ag} / \mathrm{AgCl}$. During this stage, the current density increases slowly. Global chronoamperometry measurements were performed within this region at $-1320 \mathrm{mV}$ vs. $\mathrm{Ag} / \mathrm{AgCl}$ for $60 \mathrm{~s}$, and the surface changes that were induced were quantified by
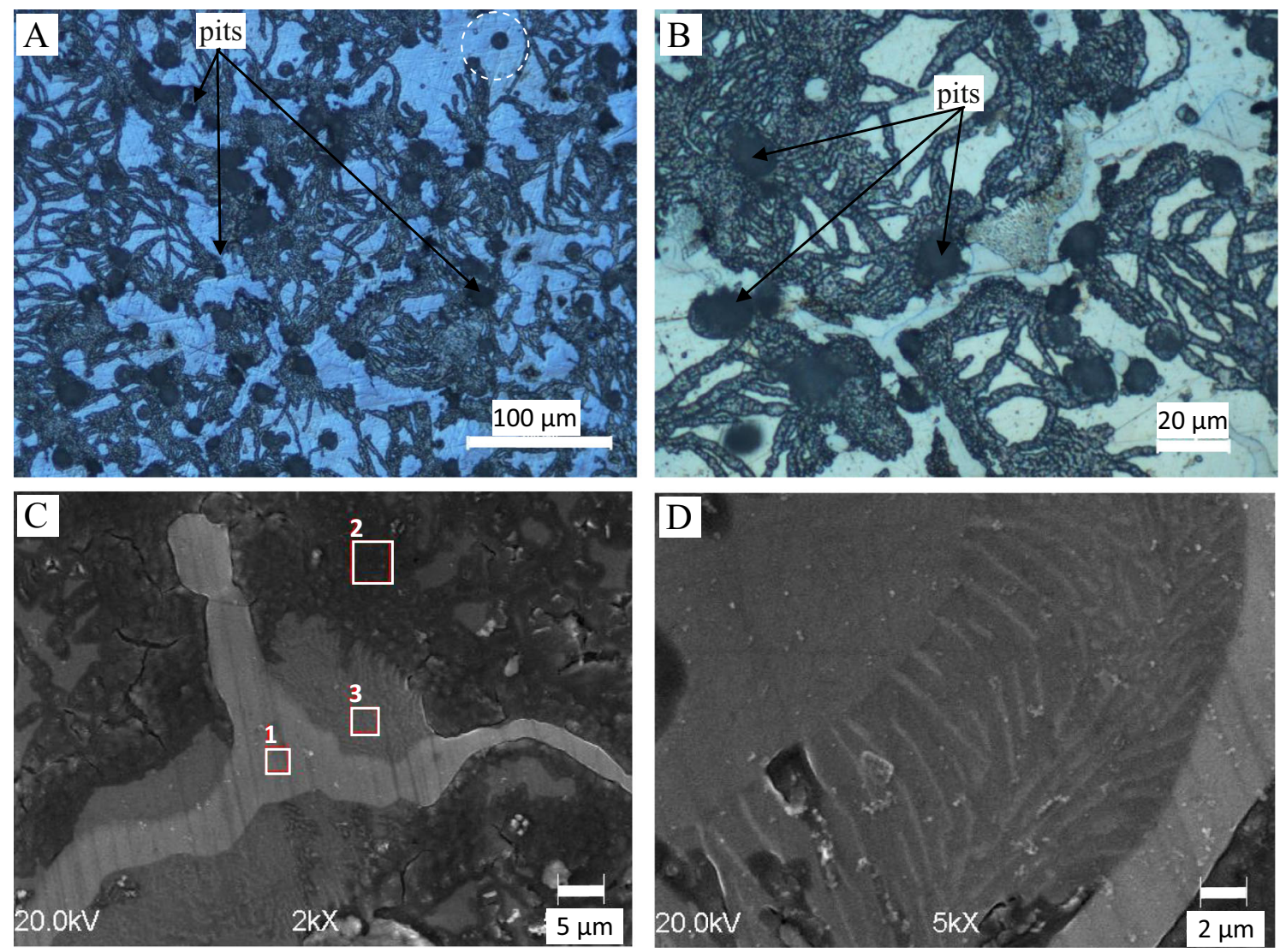

Fig. 9 a-b Optical and c-d FE-SEM micrographs of the AZ91 surface after global chronoamperometry test in $0.1 \mathrm{M} \mathrm{Na}_{2} \mathrm{SO}_{4}$ at $-1240 \mathrm{mV}$ vs. $\mathrm{Ag} / \mathrm{AgCl}$ for $60 \mathrm{~s}$ 
using optical miroscopy and FE-SEM/EDS (Fig. 8). The matrix is heavily oxidised. Indeed, a large amount of oxygen was detected by means of FE-SEM/EDS measurements in the matrix (site 2 of Fig. $8 \mathrm{a}$ and site 1 of Fig. 8b, results in Table 2). The fact that sulphur species were detected indicates that $\mathrm{SO}_{4}{ }^{2}$ ions are adsorbed. We also found that $\beta-\mathrm{Mg}_{17}(\mathrm{Al}, \mathrm{Zn})_{12}$ is slightly oxidised (site 1 of Fig. $8 \mathrm{a}$ and site 2 of Fig. 8b, results in Table 2). The slight oxidation at these last two sites ( $\beta$ phase) is caused by the presence of a high amount of aluminium in the particles. In addition, small quantities (less than 0.3 at.\% in Table 2) of sulphur species were detected at these two sites. Therefore, the evolution of the current density observed in the first stage of the polarisation curve can be attributed to the formation of $\mathrm{Mg}(\mathrm{OH})_{2}$, which hinders anodic reactions and the adsorption of $\mathrm{SO}_{4}{ }^{2-}$ ions. Optical observations conducted at low spatial resolution indicate that oxidation occurs over the whole specimen surface (Fig. 8c). These observations also reveal that filiform corrosion starts during the first stage of the polarisation curves. This corrosion mode is observed because of the formation of a highly resistant oxide film due to strong oxidation of the surface during this stage.

The second stage of the polarisation curve corresponds to potentials greater than $E_{\mathrm{b} 2}=-1270 \mathrm{mV}$ vs. $\mathrm{Ag} / \mathrm{AgCl}$ and is characterised by a rapid rise in the anodic current density. Global chronoamperometry measurements were performed at $-1240 \mathrm{mV}$ vs. $\mathrm{Ag} / \mathrm{AgCl}$ for $60 \mathrm{~s}$ (second region of the polarisation curve, grey curve in Fig. 7). Optical microscopy conducted after this test reveals the presence of numerous pits with a diameter of approximately $20 \mu \mathrm{m}$ at the specimen surface (Fig. 9a, b). The evolution of the current density in the second stage of the polarisation curve can be attributed to the breakdown of the $\mathrm{Mg}(\mathrm{OH})_{2}$ film (formed during the first stage) and the dissolution of the alloy. A surface analysis revealed that sites located within the matrix (away from pits), eutectic structure and $\beta-\mathrm{Mg}_{17}(\mathrm{Al}, \mathrm{Zn})_{12}$ all have roughly the same chemical composition as in the first stage. Results derived from EDS measurements corresponding to the sites visible in Fig. 9c are reported in Table 2. These results also show that the sample is not significantly oxidised during the second stage of the polarisation curve. However, the $\alpha-\mathrm{Mg}$ solid solution located between the ultrathin $\beta-\mathrm{Mg}_{17}(\mathrm{Al}, \mathrm{Zn})_{12}$ precipitates in the eutectic structure starts to oxidise (Fig. 9d). This is not observed in the first region of the polarisation curve (Fig. 7).

After the alloy was immersed in $0.1 \mathrm{M} \mathrm{Na}_{2} \mathrm{SO}_{4}$ at $-1240 \mathrm{mV}$ vs. $\mathrm{Ag} / \mathrm{AgCl}$ (second stage) for $60 \mathrm{~s}$, filiform corrosion continues to grow. This is clearly visible in Fig. 9a, b. We also observe that filaments propagate in different directions and never intersect. It appears that a filament would stop in its path upon encountering another filament. Observations conducted at high spatial resolution (Fig. 10a, b) reveal that no filaments propagate in either the eutectic structure or the $\beta$-phase. Indeed, they only propagate in the $\alpha-\mathrm{Mg}$ matrix. The reason for the development of such filiform corrosion is that a resistant oxide film was
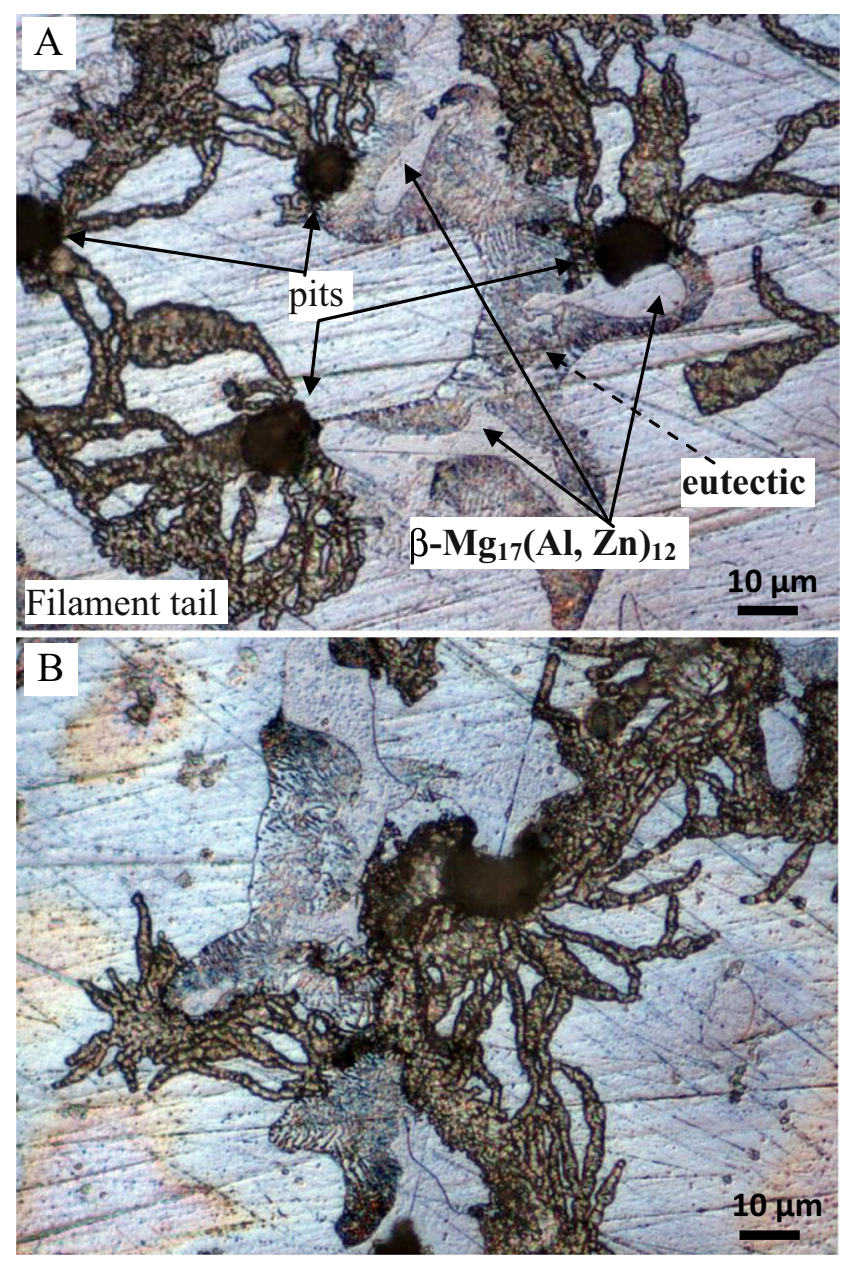

Fig. 10 a-b Optical micrographs of the AZ91 surface after global chronoamperometry test in $0.1 \mathrm{M} \mathrm{Na}_{2} \mathrm{SO}_{4}$ at $-1240 \mathrm{mV}$ vs. $\mathrm{Ag} / \mathrm{AgCl}$ for $60 \mathrm{~s}$

formed on the matrix during the first stage. The presence of this resistant surface film was revealed by EDS measurements. Filiform corrosion has previously been observed in pure magnesium [13, 49-56] as well as $\mathrm{Mg}-\mathrm{Al}[57,58], \mathrm{Mg}-\mathrm{Y}$ [50], $\mathrm{Mg}-$ 8Li [55], AM30 [59], AZ31 [60, 61], AZ80 [60], AZ91D [13] and AZ91 [51] alloys after immersion in chloride-containing solutions. It has been found that the propagation of filaments occurs with voluminous gas evolution at the head while the body immediately behind it passivates [62]. Filiform corrosion has been observed in high purity magnesium of unpolarised and galvanostatically polarised specimen in aqueous sodium chloride electrolyte $[52,56]$. A relatively widespread surface coverage of what is the typically observed filiform-like corrosion morphology [63] was observed for pure Mg. The presence of alloyed As $(0.37 \%)$ decreases cathodic reaction and modifies the resultant corrosion morphology upon $\mathrm{Mg}$, mitigating the typically observed filiform-like corrosion [64]. It has also been established that the cathodic reaction of filiform corrosion in magnesium alloys is driven by hydrogen evolution [48]. To our knowledge, until now, filiform corrosion has never been observed in $\mathrm{Mg}$ alloys in $\mathrm{Na}_{2} \mathrm{SO}_{4}$-based solutions. 
Numerous pits also initiate during the second stage (Figs. 9a, b and 10). The filiform corrosion appears to be the forerunner of regular pitting [16]. Indeed, only one pit, encircled in Fig. 9a, was not connected to any filaments.

According to local measurements, sites containing the matrix located in the centre of dendrites (black curve in Fig. 7a) and sites containing the matrix close to $\beta$-phase (red curve in Figs. 7a and 11(a1) and (b1)) undergo pitting corrosion during the first stage of the global polarisation curve. Sites containing the matrix + $\mathrm{AlMn}$ remain passive up to $0 \mathrm{mV}$ vs. $\mathrm{Ag} / \mathrm{AgCl}$
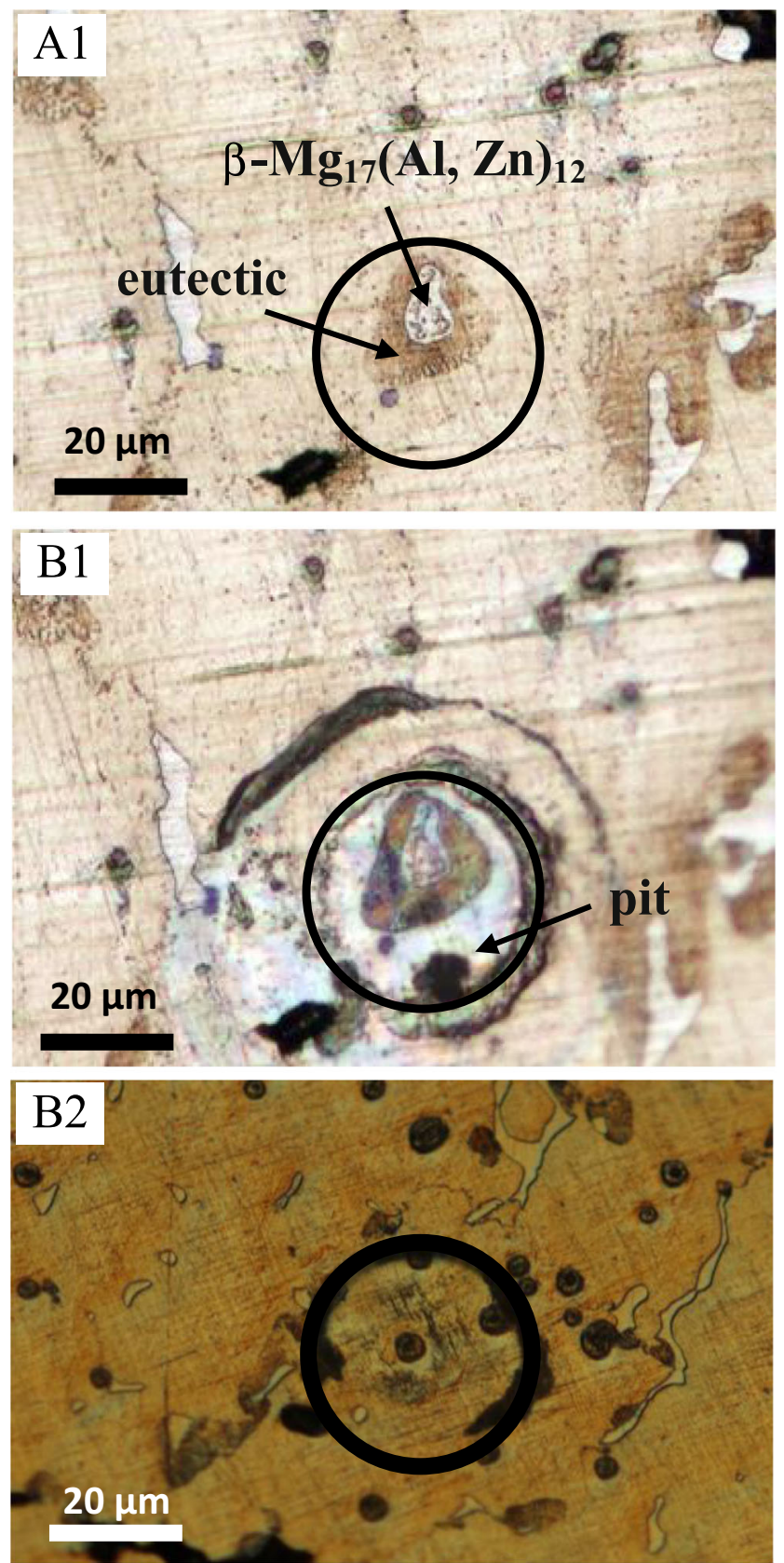

Fig. 11 Optical micrographs of the AZ91 surface after: (al) mechanical polishing and (b1-b2) local electrochemical measurements (polarisation curves) in $0.1 \mathrm{M} \mathrm{Na}_{2} \mathrm{SO}_{4}$. The diameter of the capillary (black circles) was $35 \mu \mathrm{m}$ (blue curves in Fig. 7a). This is confirmed from surface observations (Fig. 11(b2)). Filiform corrosion is never observed using local techniques. As it was already demonstrated by means of OCP vs. time (Fig. 6) and local polarisation curves (Fig. 7), the amount of dissolved oxygen quickly decreases in the capillary, preventing the formation of a resistant oxide film. Under these specific conditions, filiform corrosion cannot develop. Indeed, this type of corrosion is typically associated with a metal surface having a protective coating or a highly resistant oxide film.

To confirm the previous hypothesis, global chronoamperometry test was performed at $-1240 \mathrm{mV}$ vs. $\mathrm{Ag} /$ $\mathrm{AgCl}$ for $60 \mathrm{~s}$ in deaerated $0.1 \mathrm{M} \mathrm{Na}_{2} \mathrm{SO}_{4}$. The solution was deaerated by bubbling with argon gas for $1 \mathrm{~h}$. The content of dissolved oxygen in the solution is then low. These conditions are close to those found in the capillary (although it is impossible to measure the content of dissolved oxygen in the capillary). As shown in Fig. 12, filiform corrosion is significantly hindered. Only a few filaments are visible, whereas numerous filaments are observed after global chronoamperometry test in aerated $0.1 \mathrm{M} \mathrm{Na}_{2} \mathrm{SO}_{4}$ (Fig. 9a). This confirms the effect of the oxygen content on the corrosion behaviour to explain the occurrence of the filiform corrosion of AZ91 in $0.1 \mathrm{M} \mathrm{Na}_{2} \mathrm{SO}_{4}$ only in the global-scale measurement.

\section{Conclusions}

AZ91 has a complex microstructure. The microstructure and corrosion behaviour of as-cast AZ91 alloy was studied. The following conclusions can be drawn:

1. The results obtained in $0.1 \mathrm{M} \mathrm{NaCl}$ indicate that only pitting occurs in the alloy. Slight oxidation of the matrix is detected by means of FE-SEM/EDS. Both local and

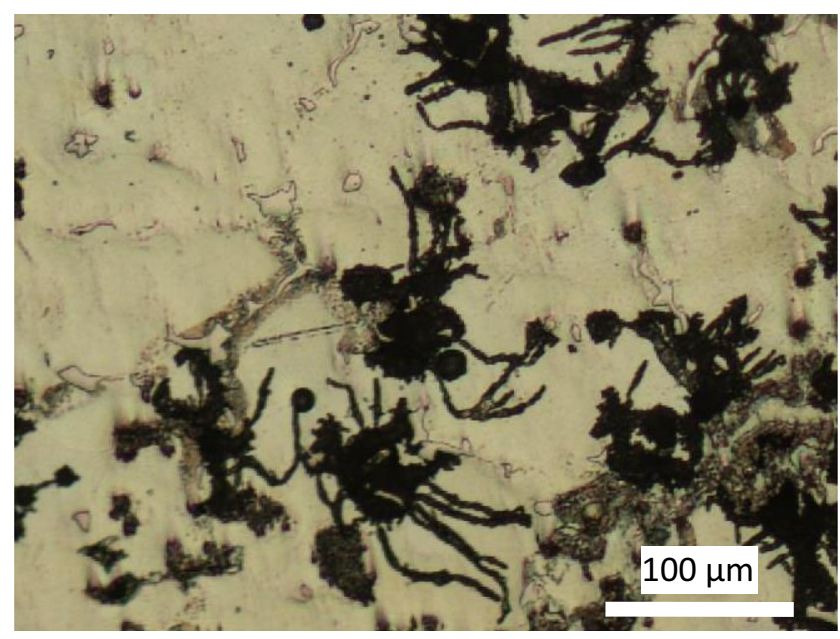

Fig. 12 Optical micrograph of the AZ91 surface after global chronoamperometry test in deaerated $0.1 \mathrm{M} \mathrm{Na}_{2} \mathrm{SO}_{4}$ at $-1240 \mathrm{mV}$ vs. $\mathrm{Ag} / \mathrm{AgCl}$ for $60 \mathrm{~s}$ 
global measurements show that AlMn precipitates have the highest corrosion resistance owing to $\mathrm{Al}$ enrichment at these sites, whereas the $\alpha-\mathrm{Mg}$ (matrix) phase is the most susceptible to corrosion. Numerical values of pitting potentials and current densities in the cathodic branch and in the current plateau have been proposed. Under these conditions (only pitting corrosion is observed), the multiscale approach can be applied to AZ91 in $0.1 \mathrm{M} \mathrm{NaCl}$.

2. By contrast, the multiscale cannot be applied to AZ91 in $0.1 \mathrm{M} \mathrm{Na}_{2} \mathrm{SO}_{4}$ because corrosion mechanisms were affected by the microcell geometry. Using the classical cell, a two-stage breakdown mechanism has been identified for corrosion in $\mathrm{Na}_{2} \mathrm{SO}_{4}$ solution. During the first stage, a highly resistant oxide film forms on the matrix, while AlMn precipitates and the $\beta$-phase undergo slight oxidation. Fifliform also starts to grow (due to the presence of the highly resistant oxide film at the specimen surface). During the second stage, pitting occurs in the matrix, and filiform corrosion continues to grow. Filiform corrosion is not observed using local techniques. It was proposed that the dissolved oxygen is quickly consumed in the capillary, preventing strong oxidation of the specimen surface (and therefore preventing filiform corrosion). This was confirmed from global chronoamperometry test performed in deaerated solution. Under these conditions, filiform corrosion is significantly hindered.

These results show that the local techniques have to be used carefully and that local measurements have to be validated before being used to understand corrosion mechanisms. Additional experiments will be performed to explain definitively why the different local conditions in the microcell as compared with the classical electrochemical cell lead to such drastic differences in the corrosion mode in $\mathrm{Na}_{2} \mathrm{SO}_{4}$ but not in $\mathrm{NaCl}$.

Open Access This article is distributed under the terms of the Creative Commons Attribution 4.0 International License (http:// creativecommons.org/licenses/by/4.0/), which permits unrestricted use, distribution, and reproduction in any medium, provided you give appropriate credit to the original author(s) and the source, provide a link to the Creative Commons license, and indicate if changes were made.

\section{References}

1. Ghali E, Dietzel W, Kainer KU (2004) J Mater Eng Perform 13: 517-529

2. Kojima Y (2000) Mater Sci Forum 350-351:3-17

3. Shaw BA (2003) Corrosion fundamentals, testing and protection. ASM Int ASM Handb 13A:692-696

4. Singh Raman RK (2004) Metall Mater Trans 35A:2525-2531

5. Zhang L, Cao ZY, Liu YB, Su GH, Cheng LR (2009) Mater Sci Eng 508A:129-133

6. Fan Y, Wu G, Zhai C (2066) Mater Sci Eng 433A:208-215
7. Srinivasan A, Ningshen S, Kamachi Mudali U, Pillai UTS, Pai BC (2007) Intermetallics 15:1511-1517

8. Sudholz AD, Birbilis N, Bettles CJ, Gibson MA (2009) J Alloys Compd 471:109-115

9. Wu G, Fan Y, Gao H, Zhai C, Zhu YP (2005) Mater Sci Eng 408A: 255-263

10. Zhou W, Aung NN, Sun Y (2009) Corros Sci 51:403-408

11. Nam ND, Bian MZ, Forsyth M, Seter M, Tan M, Shin KS (2012) Corros Sci 64:263-271

12. Abidin NIZ, Martin D, Atrens A (2011) Corros Sci 53:862-872

13. Ambat R, Aung NN, Zhou W (2000) Corros Sci 42:1433-1455

14. Anik M, Avci P, Tanverdi A, Celikyurek I, Baksan B, Gurler R (2006) Mater Des 27:347-355

15. Bonora PL, Andrei M, Eliezer A, Gutman EM (2002) Corros Sci 44:729-749

16. Ghali E, Dietzel W, Kainer KU (2004) J Mater Eng Perform 13:723

17. Jonsson M, Thierry D, LeBozec N (2006) Corros Sci 48:11931208

18. Lunder O, Aune TKR, Nisancioglu K (1987) Corrosion 43:291295

19. Lunder O, Lein JE, Aune TK, Nisancioglu K (1989) Corrosion 45: 741-748

20. Lunder O, Nordlien JH, Nisancioglu K (1997) Corros Rev 15:439_ 469

21. Mathieu S, Rapin C, Hazan J, Steinmetz P (2002) Corros Sci 44: 2737-2756

22. McIntyre NS, Chen C (1998) Corros Sci 40:1697-1709

23. Pardo A, Merino MC, Coy AE, Viejo F, Arrabal R, Feliu S Jr (2008) Electrochim Acta 53:7890-7902

24. Song GL, Atrens A (1999) Adv Eng Mater 1:11-33

25. Song GL, Atrens A (2003) Adv Eng Mater 5:837-858

26. Song G, Atrens A, Dargusch M (1999) Corros Sci 41:249-273

27. Song G, Atrens A, St. John D, Wu X, Nairn J (1997) Corros Sci 39: 1981-2004

28. Song G, Atrens A, St. John D, Nairn J (1997) Corros Sci 39:855875

29. Song G, Atrens A, Wu X, Zhang B (1998) Corros Sci 40:17691791

30. Song G, Bowles AL, St. John DH (2004) Mater Sci Eng 366A:74 86

31. Zhang T, Shao Y, Meng G, Cui Z, Wang F (2011) Corros Sci 53: 1960-1968

32. Zhao MC, Liu M, Song G, Atrens A (2008) Corros Sci 50:1939 1953

33. Sudholz AD, Kirkland NT, Buchheit RG, Birbilis N (2001) Electrochem Solid State Lett 14:C5-C7

34. Yang LJ, Li YF, Wei YH, Hou LF, Li YG, Tian Y (2010) Corros Sci 52:2188-2196

35. Galicia G, Pebere N, Tribollet B, Vivier V (2009) Corros Sci 51: 1789-1794

36. Chen J, Wang J, Han EH, Ke W (2009) Corros Sci 51:477-484

37. Krawiec H, Stanek S, Vignal V, Lelito J, Suchy JS (2011) Corros Sci 53:3108-3113

38. Singh Raman RK, Birbilis N, Efthimiadis J (2004) Corros Eng Sci Technol 39:346-350

39. Amar H, Vignal V, Krawiec H, Josse J, Peyre P, da Silva SN, Dick LF (2011) Corros Sci 53:3215-3221

40. Bohni H, Suter T, Assi F (2000) Surf Coat Technol 130:80-86

41. Jorcin JB, Krawiec H, Pébère N, Vignal V (2009) Electrochim Acta 54:5775-5781

42. Krawiec H, Vignal V, Akid R (2008) Electrochim Acta 53:52525259

43. Krawiec H, Vignal V, Heintz O, Ponthiaux P, Wenger F (2008) J Electrochem Soc 155:C127-C130

44. Suter T, Bohni H (2001) Electrochim Acta 47:191-199 
45. Xiaoyan L, Mingzhao L, Liuqun F, Haiyan W, Chong F, Hua M (2014) Rare Metal Mater Eng 43:0278-0282

46. Chen J, Wang J, Han E, Dong J, Ke W (2006) Mater Corros 57: 789-793

47. Chen J, Wang J, Han E, Dong J, Ke W (2007) Electrochim Acta 52: 3299-3309

48. Baril G, Pebere N (2001) Corros Sci 43:471-484

49. Hiromoto S, Yamamoto A, Maruyama N, Somekawa H, Mukai T (2008) Corros Sci 50:3561-3568

50. Liu M, Schmutz P, Uggowitzer PJ, Song G, Atrens A (2010) Corros Sci 52:3687-3701

51. Lunder O, Lein JE, Hsjevik SM, Aune TKR (1994) Werkst Korros 45:331-340

52. Ralston KD, Williams G, Birbilis N (2012) Corrosion 68:507-517

53. Ruggeri RT, Beck TR (1983) Corrosion 39:452-465

54. Schmutz P, Guillaumin V, Lillard RS, Lillard JA, Frankel GS (2003) J Electrochem Soc 150:B99-B110

55. Song Y, Shan D, Chen R, Han EH (2009) Corros Sci 51:1087-1094
56. Williams G, Birbilis N, McMurray HN (2013) Electrochem Commun 36:1-5

57. Hara N, Kobayashi Y, Kagaya D, Akao N (2007) Corros Sci 49: $166-175$

58. Nisancioglu K, Lunder O, Aune TKR (1990) In: Proc. 47th Annual World Magensium Conference, Cannes, France, 43-50

59. Song W, Martin HJ, Hicks A, Seely D, Walton CA, Lawrimore WB, Wang PT, Horstemeyer MF (2014) Corros Sci 78:353-368

60. Feliu S Jr, Pardo A, Merino MC, Coy AE, Viejo F, Arrabal R (2009) Appl Surf Sci 255:4102-4108

61. Wang L, Shinohara T, Zhang BP (2009) Mater Trans 50:2563-2569

62. Lunder O, Lein JE, Hesjevik SM, Aune TKr, Nisancioglu K (1990) In: Proc. 11th Annual Corrosion Congress, Florence (Italy) 5.2555.262

63. Williams G, McMurray HN (2008) J Electrochem Soc 155:C340

64. Birbilis N, Williams G, Gusieva K, Samaniego A, Gibson MA, McMurray HN (2013) Electrochem Commun 34:295-298 